\title{
Niskotemperaturna eutektička otapala - racionalnim dizajnom do zelenog otapala budućnosti
}

\author{
M. Radović, M. Panić, K. Radošević, \\ M. Cvjetko Bubalo*i I. Radojčić Redovniković \\ Prehrambeno-biotehnološki fakultet, Sveučilište u Zagrebu, Pierrotijeva 6, 10000 Zagreb, Hrvatska
}

\begin{abstract}
Sažetak
Niskotemperaturna eutektička otapala intenzivno se proučavaju kao ekološki prihvatljiva zamjena za štetna, u industriji tradicionalno sveprisutna organska otapala. Struktura te fizikalno-kemijska svojstva tih otapala mogu se dizajnirati za specifične namjene tako da zadovoljavaju tehnološke i ekonomske zahtjeve industrije, stoga su se pokazala vrlo učinkovitima u različitim područjima poput elektrokemije, organske sinteze i (bio)katalize, biotehnologije i prehrambene tehnologije, farmaceutskog inženjerstva te biomedicine. Ovaj rad donosi pregled znanstvene literature vezane uz karakteristična svojstva, pripravu i primjenu, ali i izazove primjene niskotemperaturnih eutektičkih otapala u industrijskom mjerilu.
\end{abstract}

Ključne riječi

Zelena kemija, zelena otapala, niskotemperaturna eutektička otapala, racionalni dizajn, dizajnirana otapala

\section{Uvod}

Otapala se svakodnevno upotrebljavaju u brojnim industrijskim procesima zbog presudne uloge u otapanju krutih komponenti, prijenosu tvari i topline te u koracima izdvajanja i pročišćavanja produkta. Procjenjuje se da hlapljiva organska otapala čine gotovo 60 \% svih industrijskih emisija te $30 \%$ svih emisija hlapljivih organskih spojeva u svijetu, uzrokujući brojne negativne učinke na okoliš (promjena klime na globalnoj razini, onečišćenje zraka, narušavanje ozonskog omotača, narušavanje ljudskog zdravlja i sl.). Povrh toga, većina tradicionalno uporabljenih organskih otapala je toksična, zapaljiva i korozivna, a njihova regeneracija i ponovna uporaba povezana je s energetski zahtjevnom destilacijom uz znatne gubitke te unakrsno onečišćenje. ${ }^{1}$ Godine 1991. kemičar P. T. Anastas je kroz program nazvan zelena kemija, koji se zasniva na prihvatljivom usuglašavanju ekonomskih i ekoloških zahtjeva tijekom proizvodnje različitih industrijski značajnih kemikalija, ukazao na potrebu za smanjenjem štetnih otapala te pronalaskom novih, ekološki prihvatljivih i neškodljivih otapala koja se mogu reciklirati. Danas je potreba za ograničavanjem hlapljivih otapala nadišla znanstvene okvire te je uključena u zakonodavstvo i politiku Europske unije u području očuvanja okoliša za razdoblje od 2010. do 2050. godine. Naime, Direktiva Europske unije o industrijskim emisijama (Direktiva 2010/75/EU) izričito zahtijeva ograničenje emisije određenih hlapljivih organskih spojeva kao i ostalih značajnih onečišćivača zraka. ${ }^{2}$

U sklopu razvoja ekološki prihvatljivih otapala trenutačno se razmatraju otapala iz obnovljivih izvora kao zamjene za otapala dobivena iz nafte te otapala s povoljnijim utjecajem na okoliš i na zdravlje ljudi, koja istodobno osiguravaju sigurnost procesa u kojima se upotrebljavaju, tzv. otapala s povoljnim EHS faktorom (engl. Environment, Health and

*Autor za dopisivanje: doc. dr. sc. Marina Cvjetko Bubalo E-pošta: mcvjetko@pbf.hr
Safety factor). Također, pri odabiru otapala za primjenu u industrijskom mjerilu iznimno je važan utjecaj njihove primjene na ukupnu ekonomsku računicu. S obzirom na navedeno, zbog netoksičnosti i nezapaljivosti te dostupnosti i niske cijene, voda se nameće kao najbolji izbor te se upotrebljava $u$ industrijskim razmjerima u postupcima polimerizacije i hidrodestilacije. Unatoč tome, zanemariva topljivost mnogih organskih i organometalnih spojeva $u$ vodi, visoko talište $\left(T_{\mathrm{t}}=0{ }^{\circ} \mathrm{C}\right)$ te visoka molarna entalpija isparavanja $\left(\Delta H_{v}=40,65 \mathrm{~kJ} \mathrm{~mol}^{-1}\right)$ glavni su ograničavajući čimbenici primjene vode kao otapala u kemijskoj i biotehnološkoj industriji. ${ }^{3}$ Stoga, unatrag 20 godina pažnja znanstvenika usmjerena je prema različitim ekološki prihvatljivim, prilagodljivim i pametnim otapalima, među kojima se ističu ionske kapljevine, superkritični i subkritični fluidi, fluorirana otapala te otapala dobivena iz prirodnih ili obnovljivih izvora (npr. niskotemperaturna eutektička otapala i otapala na bazi glicerola). ${ }^{4}$ Niskotemperaturna eutektička otapala (engl. Deep Eutectic Solvents, DES) prvi se put spominju 2003. godine u radu Abbotta i sur. kako bi se definirala smjesa amida (npr. urea, metilirani derivati uree i acetamid) i kvaterne amonijeve soli $\left(R_{1} R_{2} R_{3} R_{4} N^{+} X^{-}\right.$, gdje $\mathrm{X}^{-}$predstavlja anione $\mathrm{Br}^{-}, \mathrm{Cl}^{-}, \mathrm{BF}_{4}^{-}, \mathrm{NO}_{3}^{-}, \mathrm{F}^{-}$i $\mathrm{Cl}^{-}$) pri točno određenom molarnom omjeru. ${ }^{5}$ Talište pripravljenih smjesa bilo je znatno niže od tališta čistih komponenata, te su autori sniženje tališta dobivenih smjesa povezali sa stvaranjem vodikovih veza između komponenata smjese. Kasnije je pojam niskotemperaturnih eutektičkih otapala primijenjen i za druge smjese te definiran kao sustav dobiven stvaranjem eutektičke smjese između Lewisove ili Brønstedove kiseline i baze koja može sadržavati razne anionske i/ ili kationske vrste. ${ }^{6}$ Danas, zbog svojstava poput neznatne hlapljivosti (smanjenje onečišćenja zraka), nezapaljivosti (sigurnost procesa), biorazgradljivosti i niske toksičnosti (očuvanje okoliša) te mogućnosti dizajniranja za specifične svrhe, niskotemperaturna eutektička otapala pokazala su se vrlo učinkovitim otapalima u različitim područjima poput kemijske sinteze, elektrokemije, (bio)katalize, izra- 

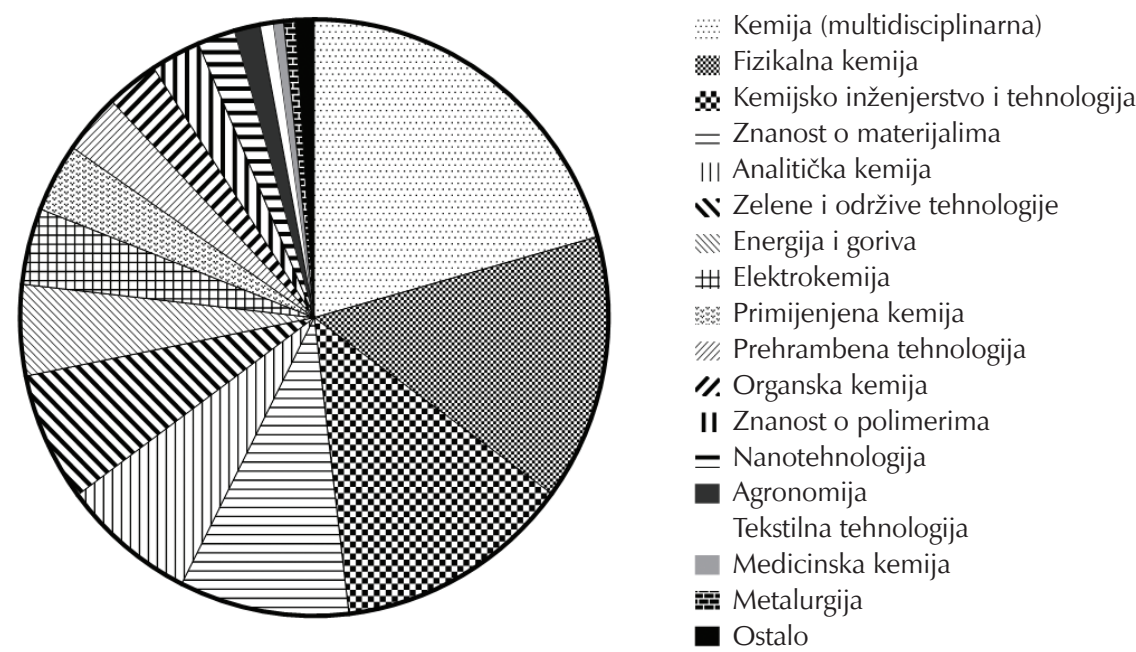

Slika 1 - Zastupljenost znanstvenih područja u kojima su objavljeni znanstveni radovi o niskotemperaturnim eutektičkim otapalima posljednjih 15 godina (baza podataka Web of Knowledge; pristupljeno 15. siječnja 2021.

Fig. 1 - Proportion of science categories in which papers describing deep eutectic solvents were published in the last 15 years (Web of Knowledge database; accessed: September 22, 2020)

de nanomaterijala, razdvajanja i analize različitih spojeva, biomedicine i $\mathrm{dr}^{7} \mathrm{U}$ razdoblju od 2005. do 2020. godine objavljeno je preko 4500 znanstvenih radova u kojima se ističu prednosti primjene niskotemperaturnih eutektičkih otapala u različitim područjima (slika 1). Opsežna rasprava o tim otapalima izvan je dosega ovog preglednog rada, međutim, opisane su njihove osnovne značajke s posebnim naglaskom na fizikalno-kemijska svojstva, pripremu i primjenu kao istinskih zelenih i učinkovitih otapala s potencijalnom industrijskom primjenom.

\section{Osnovne značajke niskotemperaturnih eutektičkih otapala}

Općenito, eutektička se otapala definiraju kao eutektička smjesa dviju ili više komponenata koje pri određenim uvjetima mogu tvoriti kapljevinu zbog formiranja jakih vodikovih veza između prisutnih komponenata. Etimološki riječ eutektik dolazi od grčkih riječi $\varepsilon v(\mathrm{eu})$ i $\tau \eta \xi \xi \varsigma$ (teksis) što znači lako topljenje, a definira se kao homogena smjesa dviju ili više čvrstih komponenata koje u jedinstvenom molarnom omjeru postižu niže talište u odnosu na pojedinačne komponente smjese. Sniženje tališta $\left(T_{t}\right)$ uzrokovano je delokalizacijom naboja uslijed formiranja snažnih intermolekulskih interakcija (npr. vodikove, ionske $\mathrm{i}$ van der Waalsove veze). U toj točki sustav djeluje kao cjelina i kruti sustavi postaju kapljeviti. ${ }^{8}$ Pojam niskotemperaturna eutektička otapala odnosi se na eutektičke smjese kod kojih dolazi do značajnog sniženja $T_{\mathrm{t}}$ te su ove smjese često kapljevine pri sobnoj temperaturi. Primjerice, miješanjem kolin klorida $\left(T_{\mathrm{t}}=302{ }^{\circ} \mathrm{C}\right) \mathrm{s}$ ureom $\left(T_{\mathrm{t}}=132{ }^{\circ} \mathrm{C}\right) \mathrm{u} \mathrm{mo-}$ larnom omjeru $1: 2$, pri povišenoj temperaturi $\left(50{ }^{\circ} \mathrm{C}\right)$ uz neprestano miješanje dobiva se niskotemperaturno eutektičko otapalo s talištem od $12{ }^{\circ} \mathrm{C}$, što je znatno niže u odnosu na talište pojedinih komponenata. ${ }^{7,9}$ Zbog odsutnosti jasne definicije niskotemperaturnog eutektičkog otapala, taj se izraz često pogrešno primjenjuje u literaturi. Nave- deni je problem vjerojatno povezan s ograničenim brojem znanstvenih radova posvećenih razumijevanju prirode tih otapala te nedovoljno jasnoj razlici te skupine otapala u odnosu na konvencionalne eutektičke smjese. Stoga, termodinamička karakterizacija, točnije izrada preciznih faznih dijagrama te razumijevanje interakcija komponenti u kapljevitoj fazi iznimno su bitni za učinkoviti dizajn i odabir najboljeg niskotemperaturnog eutektičkog otapala za određenu primjenu. ${ }^{6}$

\subsection{Struktura niskotemperaturnih eutektičkih otapala}

Niskotemperaturna eutektička otapala mogu se opisati općom formulom $\mathrm{Cat}^{+} X^{-} \mathrm{Z} Y$, pri čemu je $\mathrm{Cat}^{+}$amonijev, sulfonijev ili fosfonijev kation, a $X$ Lewisova baza, obično, halogenid. $\mathrm{Cat}^{+} X^{-}$zajedno predstavljaju akceptor vodikove veze (engl. hydrogen bond acceptor, HBA). Donor vodikove veze (engl. hydrogen bond donor, HBD), Lewisova ili Brønstedova kiselina ( $Y$ ) tvori "kompleks" s $X^{-}$, a u glavnoj formuli z označava broj molekula Y. Niskotemperaturna eutektička otapala se obično dijele na četiri vrste: tip I (kvaterna sol $\mathrm{Cat}^{+} X^{-} \mathrm{i}$ halogenid metala poput Zn, Sn, Fe), tip II (kvaterna sol $\mathrm{Cat}^{+} X^{-} \mathrm{i}$ halogenid metala poput $\mathrm{Cr}$, Co, $\mathrm{Fe}$ ), tip III (kvaterna sol $\mathrm{Cat}^{+} \chi^{-}$i donor vodikove veze poput amida, kiseline i alkohola) i tip IV (halogenid metala i donor vodikove veze poput amida i alkohola). ${ }^{10}$ Većina niskotemperaturnih eutektičkih otapala su tipa III budući da se temelje na mješavini jeftinih i lako dostupnih spojeva: netoksične kvaterne amonijeve soli $\mathrm{Cat}^{+} X^{-}$koja predstavlja akceptor vodikove veze (npr. etilamonijev klorid, kolin klorid $\mathrm{i}$ betain) te nenabijenog donora vodikove veze $Y$ poput šećera (npr. glukoza, ksiloza i saharoza), poliola (npr. ksilitol, sorbitol, etilen-glikol i glicerol), amida (npr. urea) i organskih kiselina (npr. mliječna kiselina i jabučna kiselina) (slika 2). Nadalje, uz opisane donore i akceptore vodikove veze, voda također može ulaziti u sastav niskotemperaturnih eutektičkih otapala budući da je idealan spoj za stvaranje vodikove veze (dva vodika na dva elektronska oblaka 
na kisiku). Također, prisutnost određene količine vode u niskotemperaturnom eutektičkom otapalu doprinosi smanjenju viskoznosti i gustoće otapala, što je iznimno važno kod njegove primjene. ${ }^{11}$ Do sada je pripravljen i okarakteriziran velik broj strukturno različitih niskotemperaturnih eutektičkih otapala, a najzastupljenija kvaterna sol koja se upotrebljava kao akceptor vodikove veze je kolin klorid. Budući da je jeftin, biorazgradljiv i netoksičan, kolin klorid opće je prihvaćen za upotrebu u različitim vrstama prehrambenih, farmaceutskih i kozmetičkih proizvoda. ${ }^{12,13}$ Razmatrajući osnovnu formulu kvaternog amonijeva halogenida $\left(\left[\mathrm{R}_{1} \mathrm{R}_{2} \mathrm{R}_{3} \mathrm{R}_{4} \mathrm{~N}^{+}\right] \mathrm{X}^{-}\right)$kao akceptora vodikove veze, uviđa se da promjenom alkilne grupe i/ili aniona, može nastati velik broj različitih kvarternih amonijevih soli, tj. potencijalnih akceptora vodikove veze za pripravu niskotemperaturnih eutektičkih otapala. Sukladno navedenom, kao i velikom broju mogućih donora vodikove veze, procjenjuje se da je moguće pripremiti mnogo strukturnih varijacija tih otapala $\left(>10^{8}\right) \cdot{ }^{14}$

Budući da su niskotemperaturna eutektička otapala smjesa određenih komponenti, u literaturi se obično označuju imenujući sastavnice smjese (punim nazivom ili kraticom izvedenom iz engleskog jezika), uz naznaku njihova molarnog omjera. Primjerice, niskotemperaturno eutektičko otapalo koje sačinjavaju kolin klorid i urea u molarnom omjeru $1: 2$ obično se imenuje kao kolin klorid : urea (1:2) ili, ako se primjenjuju kratice komponenata, $\mathrm{ChCl}: \mathrm{U}(1: 2)$. Također, kako bi kratice tih otapala bile što usklađenije prema međunarodnim preporukama (npr. IUPAC), molarni bi se omjer, primjerice, za već spomenuto otapalo kolin klorid : urea trebao označavati u zagradi u obliku $n_{\mathrm{A}}: n_{\mathrm{D}}=1: 2$, gdje $n_{\mathrm{A}}: n_{\mathrm{D}}$ predstavlja omjer broja molova akceptora vodikove veze naspram broja molova donora vodikove veze ili jednostavno u zagradi u obliku: molarni odnos $1: 2$. Trenutačno su u literaturi oznake i kratice nazivlja niskotemperaturnih eutektičkih otapala često nedosljedne, te bi bilo korisno razviti ujednačen sustav (tablica 1).

Prema strukturi, odnosno funkciji niskotemperaturnih eutektičkih otapala, uvedeni su različiti pojmovi kojima se definiraju podvrste tih otapala. Pod pojmom prirodna niskotemperaturna eutektička otapala (engl. Natural Deep Eutectic Solvents, NADES) podrazumijevaju se otapala kod kojih su ishodne komponente iz prirodnih izvora, poput poliola, šećera, organskih kiselina, aminokiselina i masnih kiselina. Budući da se ta otapala pripravljaju iz staničnih metabolita, pretpostavlja se da su niske toksičnosti, što je za većinu do sada sintetiziranih NADES-a i dokazano. Nedavno je uveden i pojam terapeutska niskotemperaturna eutektička otapala (engl. Therapeutic Deep Eutectic Solvents, THEDES) kao nova klasa eutektičkih otapala s mogućom primjenom u dizajniranju i formulaciji lijekova. Ta se otapala temelje na činjenici da djelatna tvar lijeka (engl.

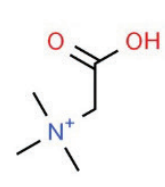

betain (B)<smiles>CCN</smiles>

etilamonijev klorid (EAC)<smiles>C[N+](C)(C)CCO</smiles>

kolin klorid $(\mathrm{ChCl})$<smiles>C[N+](C)(C)CCO</smiles>

kolin-dihidrogen fosfat (ChDHP)

$\mathrm{Cl}-\mathrm{Zn}-\mathrm{Cl}$

cinkov klorid $\left(\mathrm{ZnCl}_{2}\right)$
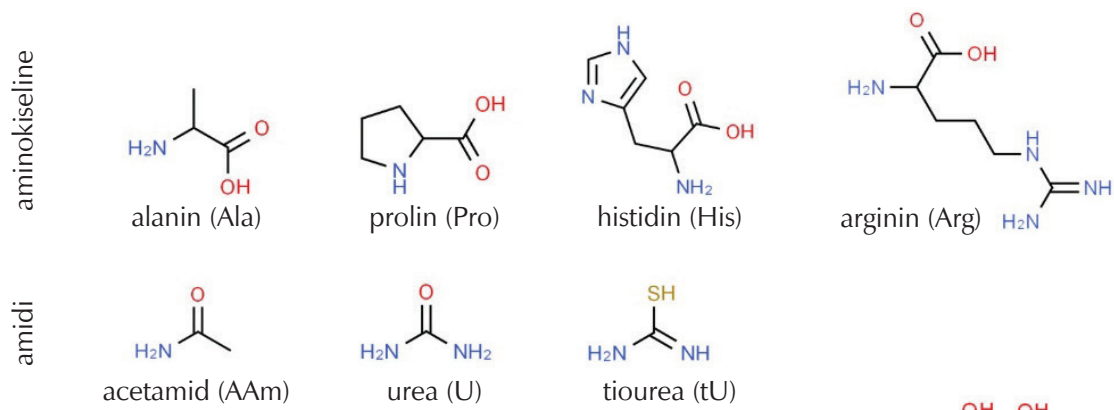

$$
\overbrace{\mathrm{H}_{2} \mathrm{~N}}^{\stackrel{\mathrm{N}}{\mathrm{NH}_{2}}}
$$<smiles>N=C(N)S</smiles>
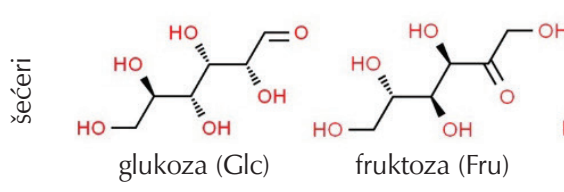

fruktoza (Fru)
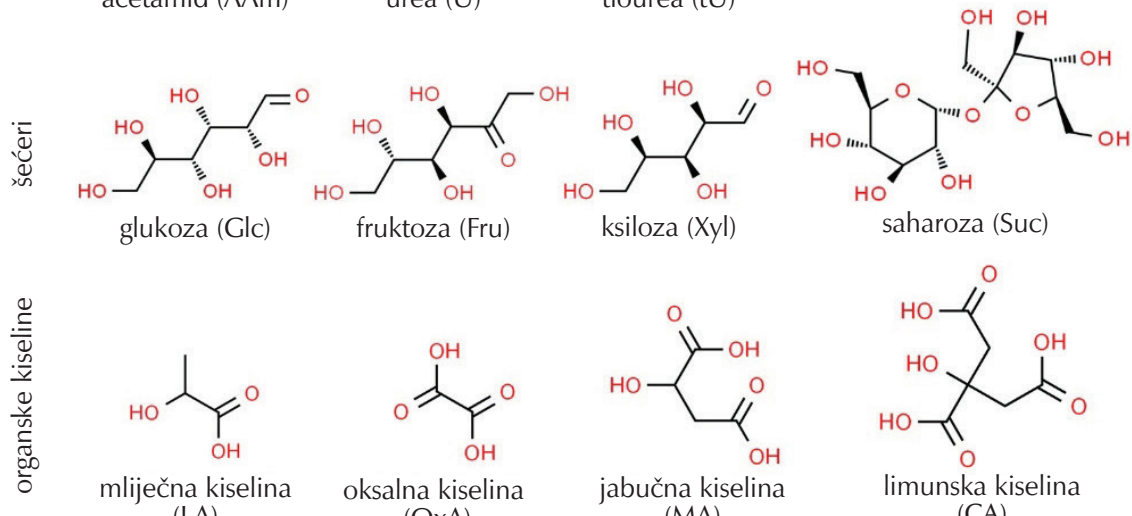

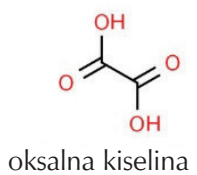

(OxA)
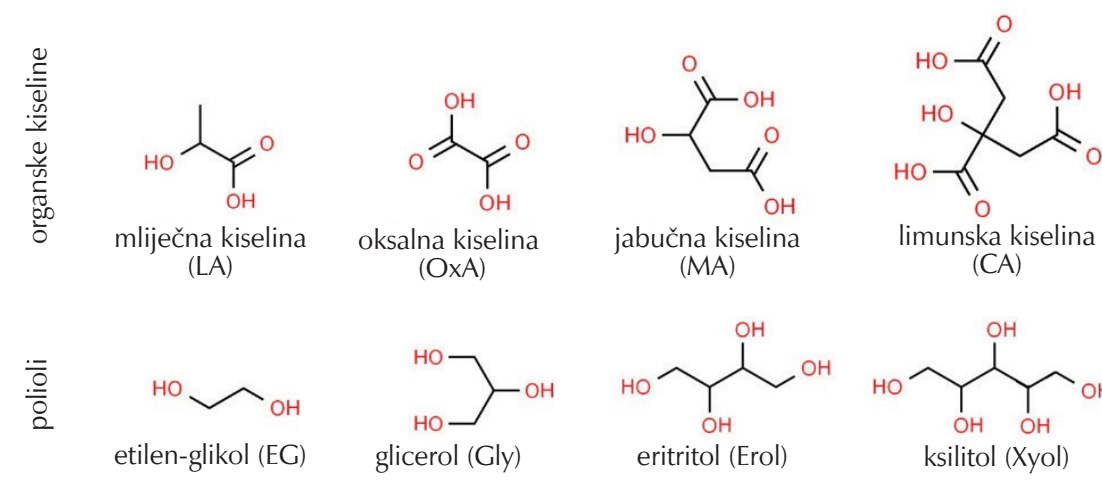
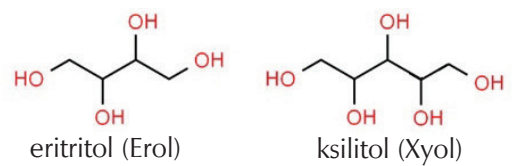

Slika 2 - Primjeri spojeva za pripravu niskotemperaturnih eutektičkih otapala

Fig. 2 - Examples of compounds for deep eutectic solvent synthesis 
Active Pharmaceutical Ingredient, API) može biti jedna od komponenti niskotemperaturnog eutektičkog otapala. Sve građevne jedinice takvog otapala međusobnim vodikovim ili ionskim vezama postižu strukturu niskotemperaturnog eutektičkog otapala, a time se može poboljšati topljivost, biodostupnost te kontrolirano otpuštanje djelatne tvari lijeka. ${ }^{15,16}$

\subsection{Priprava niskotemperaturnih eutektičkih otapala}

Ta se otapala obično pripremaju miješanjem u pravilu krutih komponenata, točnije akceptora i donora vodikove veze, u određenom molarnom omjeru pri povišenoj temperaturi (uobičajeno od 50 do $60{ }^{\circ} \mathrm{C}$ ) uz neprestano miješanje tijekom 2 do $5 \mathrm{~h}$ do nastanka kapljevine. ${ }^{17}$ Ako je voda nužna za daljnju primjenu niskotemperaturnog eutektičkog otapala, može se dodati izravno s ostalim komponentama tijekom pripreme ili nakon pripreme u novopripravljeno otapalo.

U literaturi su navedene još neke metode pripreme niskotemperaturnih eutektičkih otapala u kojima je zajednički prvi korak miješanje akceptora i donora vodikove veze u određenom molarnom omjeru, ali se daljnji koraci provode drugačije: (1) metoda usitnjavanja uz homogenizaciju (mehanokemijski pristup) - podrazumijeva usitnjavanje komponenata u tarioniku pri sobnoj temperaturi uz neprestano miješanje do stvaranja eutektičke smjese; (2) metoda pripreme vodene otopine komponenata - komponente se najprije otapaju u vodi, a potom se voda uklanja ili uparavanjem na $50{ }^{\circ} \mathrm{C}$ pri sniženom tlaku ili liofilizacijom, pri čemu zaostaje niskotemperaturno eutektičko otapalo; (4) metoda primjenom alternativnih izvora energije - komponente se pomiješaju te se homogenizacija i zagrijavanje provodi primjenom mikrovalnog zračenja i/ili ultrazvuka. ${ }^{18,19,20,21,22}$ Metodom usitnjavanja uz homogenizaciju moguće je postići najveću čistoću tih otapala, budući da se tim pristupom izbjegava moguća degradacija komponenti (primjerice organskih kiselina) pri povišenoj temperaturi. ${ }^{18}$ Ako se neko niskotemperaturno eutektičko otapalo ne može pripremiti mehanokemijskim pristupom, najčešće se pristupa metodi zagrijavanja komponenti uz neprestano miješanje i to pri najnižoj mogućoj temperaturi kako ne bi došlo do spomenute degradacije komponenata. Primjena alternativnih izvora energije znatno skraćuje vrijeme pripreme, pa se takav pristup ističe kao najbrža metoda sinteze tih otapala. Primjerice, Cvjetko Bubalo i sur. proveli su pripremu niskotemperaturnog eutektičkog otapala uz pomoć mikrovalnog zračenja i ultrazvuka, što je smanjilo vrijeme pripreme za više od 7 puta u usporedbi s klasičnim postupkom priprave zagrijavanjem uz mehaničko miješanje. ${ }^{22}$ Unatoč tome, klasični postupak priprave zagrijavanjem uz mehaničko miješanje najzastupljeniji je u literaturi zbog praktičnosti provedbe te zbog mogućnosti održavanja konstantne temperature (npr. primjenom ultrazvuka dolazi do naglih lokalnih porasta temperature smjese uslijed fenomena kavitacije).

\subsection{Fizikalno-kemijska svojstva niskotemperaturnih eutektičkih otapala}

Najvažnije fizikalno-kemijske karakteristike tih otapala, poput tališta $\left(T_{t}\right)$, viskoznosti $(\eta)$, gustoće $(\rho)$, polarnosti $\left(E_{\mathrm{NR}}\right)$ i pH značajno ovise o strukturi komponenata koje ga tvore te o njihovom molarnom omjeru (tablica 1 ).

Općenito, ta otapala imaju talište niže od $150{ }^{\circ} \mathrm{C}$, no niskotemperaturna eutektička otapala koja se najviše primjenjuju imaju talište ispod $50{ }^{\circ} \mathrm{C}$, pa se mogu upotrebljavati i na sobnoj temperaturi. Dokazano je da se povećanjem broja hidroksilnih grupa u molekuli koja djeluje kao donor vodikove veze povećava vrijednost tališta. Tako, primjerice, otapalo na bazi kolin klorida kao akceptora vodikove veze s glicerolom (alkohol s tri hidroksilne grupe) kao donorom vodikove veze ima talište $T_{\mathrm{t}}=-40^{\circ} \mathrm{C}$, dok otapalo $\mathrm{s}$ istim akceptorom vodikove veze s etilen-glikolom (alkohol s dvije hidroksilne grupe) kao donorom vodikove veze ima talište $T_{\mathrm{t}}=-66^{\circ} \mathrm{C} .{ }^{8}$

Gustoća niskotemperaturnih eutektičkih otapala obično je veća od gustoće vode i tradicionalnih organskih otapala (npr. etanol, metanol, etil-acetat, $n$-heksan i dr.) i kreće se u rasponu $\rho=1,1-1,4 \mathrm{~g} \mathrm{~cm}^{-3}$. Također, većina poznatih otapala pokazuje visoke vrijednosti viskoznosti u rasponu $\eta=0,02-0,5 \mathrm{~Pa} \mathrm{~s}$ pri $40^{\circ} \mathrm{C}$ (za usporedbu, viskoznost vode iznosi $\eta=0,0006 \mathrm{~Pa} \mathrm{~s}$ pri $40{ }^{\circ} \mathrm{C}$ ). Struktura tih otapala, odnosno struktura sirovina iz kojih se pripremaju, znatno utječe na spomenute karakteristike, pa su tako, primjerice, otapala na bazi kolin klorida sa šećerom kao donorom vodikove veze najviskoznija i najgušća, dok su ona na bazi poliola najmanje gusta i viskozna. Pored prirode spojeva koji tvore niskotemperaturno eutektičko otapalo, njihov molarni omjer, kao i temperatura imaju snažan utjecaj na gustoću i viskoznost tih otapala. Primjerice, na sobnoj temperaturi gustoća i viskoznost niskotemperaturnog eutektičkog otapala kolin klorid : glukoza $\left(n_{\mathrm{A}}: n_{\mathrm{D}}=1: 1\right) \mathrm{s}$ 30 vol. \% vode iznosi $\rho=1,176 \mathrm{~g} \mathrm{~cm}^{-3}$ i $\eta=0,0226$ Pa s, dok je za otapalo kolin klorid : etilen-glikol $\left(n_{\mathrm{A}}: n_{\mathrm{D}}=1: 2\right)$ s 30 vol. \% vode $\rho=1,092 \mathrm{~g} \mathrm{~cm}^{-3} \mathrm{i} \eta=0,0069 \mathrm{~Pa} \mathrm{~s}^{23,24}$ Povećanje temperature dovodi do veće molekularne aktivnosti i pokretljivosti atoma u molekulama, čime se povećava molarni volumen otopine te smanjuje gustoća i viskoznost niskotemperaturnog eutektičkog otapala. Naposljetku, gustoća i viskoznost mogu se mijenjati odnosno prilagođavati dodavanjem vode. Točnije, dodatkom vode niskotemperaturnom eutektičkom otapalu smanjuje se njegova viskoznost i gustoća. ${ }^{23,25,26}$ Međutim, treba imati na umu da bi previsok udio vode u otapalu (procijenjeno na maseni udio $>40-50 \%$ ) mogao razbiti supramolekularni kompleks donor-akceptor vodikove veze, što bi u konačnici rezultiralo vodenom otopinom pojedinih komponenata otapala zbog gubitka mreže vodikovih veza među njima. ${ }^{26}$ Hammond i sur. proučavali su utjecaj dodatka vode na nanostrukturu niza niskotemperaturnih eutektičkih otapala na bazi kolin klorida i uree te pokazali da se nanostruktura otapala zadržava pri visokoj razini voda (oko 42 mas. \%,) zbog solvofobne sekvestracije vode u nanostrukturirane domene oko kolinijeva kationa. Nadalje, pri masenom udjelu vode većem od 51 \% struktura otapala je narušena te prevladavaju interakcije voda - voda i otapalo - voda. ${ }^{27}$

Očekivano, priroda komponenti koje sačinjavaju niskotemperaturno eutektičko otapalo određuje i njegovu ki- 
Tablica 1 - Svojstva često primjenjivanih niskotemperaturnih eutektičkih otapala na bazi kolin klorida ${ }^{32}$

Table 1 - Properties of commonly used choline chloride-based deep eutectic solvents ${ }^{32}$

\begin{tabular}{|c|c|c|c|c|c|c|c|c|c|c|c|c|c|}
\hline \multirow{3}{*}{ HBA : HBD } & \multirow{3}{*}{ Kratice } & \multirow{3}{*}{$n_{\mathrm{A}}: n_{\mathrm{D}}$} & \multirow{3}{*}{$\begin{array}{l}W_{\mathrm{H}_{2} \mathrm{O}} \\
/ \%\end{array}$} & \multirow{3}{*}{$\begin{array}{c}\rho^{*} / \\
\mathrm{g} \mathrm{cm}^{-3}\end{array}$} & \multirow{3}{*}{$\begin{array}{l}\eta^{*} / \\
\text { Pas }\end{array}$} & \multirow{3}{*}{$\mathrm{pH}^{*}$} & \multirow{3}{*}{$\begin{array}{c}E_{\mathrm{NR}} / \\
\mathrm{kcal} \mathrm{mol}^{-1}\end{array}$} & \multirow{3}{*}{$\begin{array}{l}\text { Cijena } \\
/ € \mathrm{~kg}^{-1 * *}\end{array}$} & \multirow{2}{*}{\multicolumn{4}{|c|}{$\begin{array}{l}E C_{50} / \mathrm{mg} \mathrm{ml}^{-1} \\
\text { Stanične linije }\end{array}$}} & \multirow{3}{*}{ Lit. } \\
\hline & & & & & & & & & & & & & \\
\hline & & & & & & & & & HeLa & HEK 293T & $\mathrm{CCO}$ & MCF-7 & \\
\hline \multirow{5}{*}{$\begin{array}{l}\text { Kolin klorid: } \\
\text { etilen-glikol }\end{array}$} & \multirow{5}{*}{$\mathrm{ChCl}: \mathrm{EG}$} & \multirow{5}{*}{$1: 2$} & 0 & 1,120 & 0,0370 & - & - & 65,685 & \multirow{5}{*}{-} & \multirow{5}{*}{-} & \multirow{5}{*}{$>2000$} & \multirow{5}{*}{$>2000$} & \multirow{5}{*}{$26,33,34$} \\
\hline & & & 10 & 1,114 & 0,0204 & 7,73 & - & 59,12 & & & & & \\
\hline & & & 30 & 1,092 & 0,0069 & 7,0 & 50,63 & 45,99 & & & & & \\
\hline & & & 50 & 1,066 & 0,0034 & 5,93 & 50,1 & 32,86 & & & & & \\
\hline & & & 80 & - & - & 5,58 & 49,93 & 13,14 & & & & & \\
\hline \multirow{5}{*}{$\begin{array}{l}\text { Kolin klorid : } \\
\text { urea }\end{array}$} & \multirow{5}{*}{$\mathrm{ChCl}: \mathrm{U}$} & \multirow{5}{*}{$1: 2$} & 0 & 1,250 & 0,75 & - & - & 69,71 & \multirow{5}{*}{$>2000$} & \multirow{5}{*}{$>2000$} & \multirow{5}{*}{$>2000$} & \multirow{5}{*}{83.5} & \multirow{5}{*}{$26,33-35$} \\
\hline & & & 10 & 1,178 & 0,0313 & 9,13 & - & 62,73 & & & & & \\
\hline & & & 30 & 1,146 & 0,0057 & 8,89 & - & 48,77 & & & & & \\
\hline & & & 50 & 1,109 & 0,0027 & 9,74 & - & 34,81 & & & & & \\
\hline & & & 80 & - & - & - & - & 13,87 & & & & & \\
\hline \multirow{5}{*}{$\begin{array}{l}\text { Kolin klorid: } \\
\text { glukoza }\end{array}$} & \multirow{5}{*}{$\mathrm{ChCl}$ : Glc } & \multirow{5}{*}{$1: 1$} & 0 & - & - & - & - & 38,45 & \multirow{5}{*}{$>2000$} & \multirow{5}{*}{-} & \multirow{5}{*}{-} & & \\
\hline & & & 10 & 1,228 & 0,8268 & 5,14 & & 34,60 & & & & & \\
\hline & & & 30 & 1,176 & 0,0226 & 4,87 & 50,63 & 26,91 & & & & $>2000$ & 26,36 \\
\hline & & & 50 & 1,123 & 0,0051 & 4,03 & 50,1 & 19,22 & & & & & \\
\hline & & & 80 & - & - & 5,17 & 49,84 & 7,68 & & & & & \\
\hline $\begin{array}{l}\text { Kolin klorid : } \\
\text { glicerol }\end{array}$ & ChCl: Gly & $1: 2$ & 0 & 1,180 & 0,259 & - & - & 33,66 & $>2000$ & - & $>2000$ & $>2000$ & $26,33,34,36$ \\
\hline
\end{tabular}

Kratice: akceptor vodikove veze/hydrogen bond acceptor (HBA), donor vodikove veze/hydrogen bond donor (HBD), omjer broja molova akceptora vodikove veze naspram broju molova donora vodikove veze/molar ratio of hydrogen bond acceptor and hydrogen bond donor $\left(n_{\mathrm{A}}: n_{\mathrm{D}}\right)$, maseni udio vode/water share $\left(w_{\mathrm{H} 2 \mathrm{O}}\right)$, gustoća/density $(\rho)$, viskoznost/viscosity $(\eta)$, polarnost/polarity $\left(E_{\mathrm{NR}}\right), 50 \%$-tna djelotvorna koncentracija/half maximal effective concentration $\left(E C_{50}\right)$

* Vrijednosti fizikalno-kemijskih svojstava $\rho, \eta$ i pH izmjerene su pri $25{ }^{\circ} \mathrm{C} /$ physicochemical parameters $\rho, \eta$ and $\mathrm{pH}$ were measured at $25{ }^{\circ} \mathrm{C}$ ** Procijenjeno na temelju Sigma-Aldrich cijena sirovina potrebnih za pripremu 1 kg otapala. $U$ obzir su uključeni molarni udjeli komponenti i maseni udio vode

selost i bazičnost. Otapala s organskom kiselinom kao donorom vodikove veze su kisela $(\mathrm{pH}<3)$. Primjerice, otapalo kolin klorid : limunska kiselina $\left(n_{\mathrm{A}}: n_{\mathrm{D}}=1: 2\right)$ ima pH vrijednost od svega 0,83. Nasuprot tome, otapala koja sadrže amid kao donor vodikove veze su bazična s pH vrijednostima $>8$, poput kolin klorid : urea $\left(n_{\mathrm{A}}: n_{\mathrm{D}}=1: 2\right) \mathrm{za}$ koju pH iznosi 8,51. ${ }^{28,29}$ Također, utvrđeno je da se obrazac povećanja pH vrijednosti s povećanjem sadržaja vode pojavljuje kod otapala s iznimno niskim pH vrijednostima, dok se kod otapala s pH u gornjem području kiselosti $\mathrm{pH}$ vrijednost smanjuje s povećanjem sadržaja vode. ${ }^{26}$

Što se tiče polarnosti, najviše upotrebljavana niskotemperaturna eutektička otapala su polarna, pri čemu su otapala na bazi organskih kiselina najpolarnija, dok su ona na bazi šećera i poliola najmanje polarna. Primjerice, polarnost niskotemperaturnog eutektičkog otapala kolin klorid : limunska kiselina $\left(n_{\mathrm{A}}: n_{\mathrm{D}}=2: 1\right)$ s 30 vol. \% vode iznosi $E_{\mathrm{NR}}=49,39 \mathrm{kcal} \mathrm{mol}^{-1}$; za kolin klorid : etilen-glikol $\left(n_{\mathrm{A}}: n_{\mathrm{D}}=1: 2\right)$ iznosi $E_{\mathrm{NR}}=50,37 \mathrm{kcal} \mathrm{mol}^{-1}$, a za kolin klorid: glukoza $\left(n_{\mathrm{A}}: n_{\mathrm{D}}=1: 1\right)$ s 30 vol. \% vode iznosi $E_{\mathrm{NR}}=50,63 \mathrm{kcal} \mathrm{mol}^{-1} \cdot{ }^{30}$ Niskotemperaturna eutektička otapala opisana u literaturi uglavnom su hidrofilnog karaktera, no posljednjih su godina istraživanja proširena i za hidrofobna otapala (npr. mentol : oktanska kiselina, $n_{\mathrm{A}}: n_{\mathrm{D}}$ $=1: 1$ ) čime se pruža mogućnost pripreme niskotempe- raturnih eutektičkih otapala različitih raspona polariteta i hidrofilnosti/hidrofobnosti. ${ }^{31}$

Zbog spomenutog širokog raspona u vrijednostima fizikalno-kemijskih karakteristika niskotemperaturna eutektička otapala smatraju se dizajniranim otapalima (engl. designer solvents) budući da je izborom sastavnica i njihovim omjerom moguće njima upravljati karakteristikama te samim time utjecati na uspješnost njihove primjene.

\section{Niskotemperaturna eutektička otapala i zelena kemija}

S obzirom na važnost zadovoljavanja principa zelene kemije kod osmišljavanja novih kemikalija i procesa, vrlo je važno detaljnije proučiti koliko niskotemperaturna eutektička otapala zaista zadovoljavaju te principe. Prema načelima zelene kemije, odabir prikladne zamjene za organska otapala temelji se na sigurnosti radnika (toksičnost, karcinogenost, mutagenost, apsorpcija putem kože i respiratornog sustava), sigurnosti procesa (zapaljivost, eksplozivnost, hlapljivost, potencijal stvaranja peroksida), sigurnosti okoliša (postojanost, ekotoksičnost, kontaminacija podzemnih voda, uništavanje ozonskog omotača) i održivosti procesa 
(sposobnost regeneracije i mogućnost višekratne uporabe). ${ }^{37}$ Prema tim smjernicama, idealno otapalo treba biti kemijski i fizički stabilno, nezapaljivo, male hlapljivosti, s povoljnim ekološkim otiskom, jednostavno za uporabu te jednostavno za regeneraciju s mogućnošću ponovne uporabe. Također, prema holističkom pristupu potrebno je dodatno uzeti u obzir rizik primjene otapala za okoliš tijekom njihova cijelog "životnog ciklusa", koji pored gore navedenih poželjnih osobina otapala uključuje i potencijalne izazove tijekom njihove priprave.

Kao što je već spomenuto, niskotemperaturna eutektička otapala su nehlapljiva, nezapaljiva i stabilna. Što se tiče njihove toksičnosti i biorazgradljivosti, pretpostavka da su ta otapala neškodljiva temelji se na podatcima o toksičnosti pojedinih komponenti koje ih sačinjavaju (većina se dobiva iz prirodnih izvora i zadovoljavaju farmaceutske standarde). Međutim, ta pretpostavka ne uzima u obzir mogućnost sinergističkog učinka komponenti, što bi moglo imati značajan utjecaj na biološka svojstva tih otapala. ${ }^{38}$ Do sada je procijenjen učinak, točnije toksičnost, pojedinih niskotemperaturnih eutektičkih otapala na različite organizme i stanične linije poput: bakterija (npr. Escherichia coli, Staphylococcus aureus, Bacillus subtilis, Pseudomonas aeruginosa, Listeria monocytogenes, Salmonella enteritidis), riba (Cyprinus carpio), vodenih rakova (Artemia salina) i biljaka (sjeme pšenice Triticum aestivum) te staničnih linija (npr. HeLa, MCF-7, CCO, CaOV3, HepG2). ${ }^{39}$ Općenito, ovisno o strukturi, niskotemperaturnih eutektička otapala pokazuju malu do umjerenu toksičnost. Dosadašnjim istraživanjima dokazano je da otapala koja uključuju organske kiseline kao donore vodikove veze (npr. oksalna, limunska, jabučna ili vinska kiselina) pokazuju veću citotoksičnost od onih koja uključuju šećere kao donore vodikove veze (npr. glukoza, manoza, fruktoza i ksiloza), što je vjerojatno povezano s niskim $\mathrm{pH}$ vrijednostima otapala koja u svojem sastavu imaju organske kiseline. ${ }^{7,35}$ Većina ispitanih niskotemperaturnih eutektičkih otapala smatra se biorazgradljivima jer su komponente koje čine otapala uglavnom prirodnog porijekla. Ta tvrdnja posebno se odnosi na spomenuta prirodna niskotemperaturna eutektička otapala u čiji sastav ulaze primarni metaboliti (aminokiseline, šećeri i sl.), koje mogu razgraditi različiti organizmi u prirodi. Nekoliko istraživačkih skupina istraživalo je biorazgradljivost različitih niskotemperaturnih eutektičkih otapala koristeći se mikroorganizmima iz urbanih ili industrijskih otpadnih voda, te su sva otapala klasificirana su kao "lako biorazgradljiva" s dobrom korelacijom između toksičnosti i biorazgradljivosti, pri čemu su se otapala s organskim kiselinama kao donorima vodikove veze razgrađivala sporije od ostalih. ${ }^{40,41,42}$

Konačno, važno je istaknuti prednosti i izazove pripreme niskotemperaturnih eutektičkih otapala u kontekstu zelene kemije. Priprava tih otapala odvija se jednostavno i pri blagim uvjetima te bez primjene dodatnih otapala ili pomoćnih tvari/katalizatora, čime se zadovoljavaju principi zelene kemije. Također, tijekom priprave troše se svi reagensi, odnosno ne dolazi do nastajanja nusproizvoda i otpada. Prema teoriji ekonomije atoma (engl. Atom economy) kojom se razmatra udio atoma upotrijebljenih u stehiometrijskoj pretvorbi kemikalija (\%) to bi značilo da za taj proces iskorištenost atoma iznosi 100 \%, što je također u skladu s principima zelene kemije. ${ }^{43}$ Također, budući da ne dolazi do nastajanja neželjenih nusproizvoda niti otpada, nije potrebno pročišćavanje pripravljenog otapala, što je također važno s ekonomskog i ekološkog stajališta. Sukladno tome, za kvantificiranje količine proizvedenog otpada korisno je odrediti okolišni faktor, E-faktor (engl. Environmental factor, E-factor), koji se definira kao kg proizvedenog otpada po kg proizvoda. ${ }^{44}$ Ako se niskotemperaturno eutektičko otapalo priprema u pravilno postavljenom molarnom omjeru akceptora i donora vodikove veze, ne dolazi do stvaranja otpada, te se može pretpostaviti da je E-faktor $=0 \mathrm{~kg} \mathrm{~kg}^{-1}$, što je idealna vrijednost tog parametra. Također, vrlo je bitna i činjenica da se kolin klorid, kao jedna od osnovnih sirovina u pripravi tih otapala, proizvodi vrlo ekonomičnim procesom u kojem gotovo nema otpada u velikim količinama. ${ }^{38}$ Također, u kontekstu zelene kemije i održivog razvoja, važno je spomenuti da su ta otapala jeftina, te se temeljem tržišne cijene sirovina trošak pripreme $\mathrm{kg}$ tih otapala procjenjuje u rasponu od 10 do $140 €$, što je usporedivo s cijenom organskih otapala. ${ }^{45}$ Ipak, otapala koja uključuju neke komponente visoke cijene, poput prolina, znatno su skuplja. Panić i sur. procijenili su da su niskotemperaturna eutektička otapala koja sadrže polialkohole dvostruko jeftinija od onih koja sadrže aminokiseline kao donore vodikove veze. Primjerice, kao jeftinije otapalo pokazalo se niskotemperaturno eutektičko otapalo kolin klorid : etilen-glikol u molarnom omjeru 1 : 2 (43,72 € kg-1), dok je znatno skuplje bilo kolin klorid : prolin : jabučna kiselina u molarnom omjeru $1: 1: 1\left(252,42 € \mathrm{~kg}^{-1}\right){ }^{30}$

\section{Primjena niskotemperaturnih eutektičkih otapala racionalnim dizajnom do idealnog otapala}

Kao što je već istaknuto u prethodnim poglavljima, budući da postoji velik broj akceptora i donora vodikove veze koji se mogu primjenjivati za pripravu niskotemperaturnih eutektičkih otapala, njihova fizikalno-kemijska svojstva mogu se značajno razlikovati, te se zahvaljujući tome može dizajnirati njihova struktura s ciljem racionalnog osmišljavanje otapala za specifične svrhe. ${ }^{8}$

Posljednjih 10 godina ta se otapala intenzivno proučavaju u: (1) području elektrokemije zbog električne provodljivosti te sposobnosti otapanja različitih metalnih soli i oksida; (2) sintetskoj kemiji i (bio)katalizi zbog sposobnosti otapanja različitih organskih i anorganskih spojeva (reaktanti, katalizatori) te stabilizaciji i povećanju selektivnosti (bio)katalizatora, ali i uloge katalizatora; (3) biotehnologiji i prehrambenoj tehnologiji u procesima ekstrakcije bioaktivnih spojeva iz prirodnih izvora zbog sposobnosti otapanja i stabilizacije različitih prirodnih spojeva; za obradu lignoceluloznih sirovina zbog sposobnosti njihova otapanja te u proizvodnji biodizela, kao rezervoar za glicerol, jedan od nusprodukata proizvodnje; (4) separacijskim procesima poput apsorpcije kiselih plinova $\left(\mathrm{CO}_{2}, \mathrm{SO}_{2}\right.$ i $\left.\mathrm{H}_{2} \mathrm{~S}\right)$, ekstrakcije dušikovih i sumporovih spojeva iz loživih ulja, separacije smjesa aromatskih i alifatskih spojeva, razdvajanje smjesa alkohola i estera, uklanjanje radioaktivnog onečišćenja; (5) farmaceutskom inženjerstvu kao otapalo za poboljšanje topljivosti slabo topljivih spojeva; sustav za kontroliranu isporuku lijeka; razvoj novih formulacija ak- 
tivnih djelatnih tvari, kao jedne od komponenti nove klase niskotemperaturnih eutektičkih otapala, tzv. terapeutskih niskotemperaturnih eutektičkih otapala; (6) biomedicini kao sredstvo za čuvanje bioloških molekula (DNK i proteina) i materijala (stanice, tkiva, biološki uzorci); za fiksiranje raznih bioloških uzoraka od organela, stanica do tkiva za potrebe različitih dijagnostičkih molekularnih metoda (primjena u imunohistokemiji, fluorescentnoj mikroskopiji, in situ hibridizaciji i drugo); za sintezu biopolimera i biorazgradljivih materijala $\mathrm{s}$ antibakterijskim djelovanjem za tikvne implantate. ${ }^{46-85}$ Pregled odabranih primjera primjene niskotemperaturnih eutektičkih otapala prikazan je u tablici 2 .

Kad se govori o primjeni niskotemperaturnih eutektičkih otapala, a što ih čini različitim od tradicionalno upotreblja- vanih otapala, važno je napomenuti da novija istraživanja ukazuju na postojanje tih otapala u živim stanicama kao trećeg medija u organizmu, uz vodu i lipide, a pretpostavlja se da su uključeni u biosintezu, otapanje i skladištenje različitih u vodi slabo topljivih metabolita i nestabilnih spojeva koji imaju važnu fiziološku i kemijsku ulogu u stanici. Stoga, niskotemperaturna eutektička bi otapala mogla biti od iznimnog značaja u biotehnologiji, biomedicini i farmaceutici budući da oponašaju prirodne uvjete u stanici za aktivaciju odnosno stabilizaciju biomolekula (npr. proteina, enzima, nukleinskih kiselina). ${ }^{86}$

S obzirom na navedeno, mogućnost dizajniranja za specifične svrhe, jednostavnu i u pravilu jeftinu pripravu, mogućnost regeneracije i ponovne uporabe te povoljan ekološki otisak, potencijal niskotemperaturnih eutektičkih

Tablica 2 - Primjena niskotemperaturnih eutektičkih otapala

Table 2 - Deep eutectic solvents applications

\begin{tabular}{|c|c|c|c|}
\hline & Niskotemperaturno eutektičko otapalo & Proces/reakcija/produkt & Ref. \\
\hline \multirow{10}{*}{ 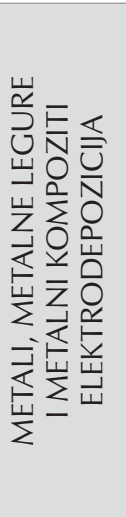 } & \multirow{7}{*}{$\mathrm{ChCl}: \mathrm{U}$} & Nanočestice (Ag) & 47 \\
\hline & & Nanokristali kontrolirane forme $(\mathrm{Au})$ & 48 \\
\hline & & Magnetski filmovi (Co, Pt) & 49 \\
\hline & & Otapanje $\mathrm{CuO}$ & 50 \\
\hline & & Elektrodepozicija (Ni) & 51 \\
\hline & & Otapanje $\mathrm{PbO} / z ̌ i c e ~ s u b m i k r o m e t r a$, prah & 52 \\
\hline & & "Nanocvijeće" za katalizu (Pt) i nanokristali & 53 \\
\hline & \multirow{3}{*}{$\mathrm{ChCl}: \mathrm{EG}$} & Nanočestice na staklenom ugljičnom nosaču (Ag) & 54 \\
\hline & & Elektrodepozicija (As) & 55 \\
\hline & & Nanočestice (Au) & 56 \\
\hline \multirow{5}{*}{ 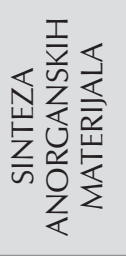 } & \multirow{3}{*}{$\mathrm{ChCl}: \mathrm{U}$} & $\mathrm{MPO}_{4}(\mathrm{M}=\mathrm{Mn}, \mathrm{Fe}, \mathrm{Co})$ & 57 \\
\hline & & Površinski modificirane čestice silike & 58 \\
\hline & & $\mathrm{Fe}_{3} \mathrm{O}_{4}$ magnetske nanočestice & 59 \\
\hline & \multirow{2}{*}{$\mathrm{ChCl}: \mathrm{EG}$} & Nanočestice niklova fosfida & 60 \\
\hline & & Nanostrukturirani filmovi niklov(II)-oksida & 61 \\
\hline \multirow{8}{*}{ 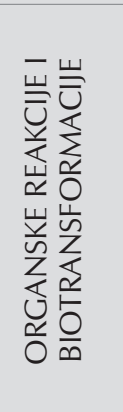 } & \multirow{4}{*}{$\mathrm{ChCl}: \mathrm{U}$} & Bromiranje supstituiranih kinona & 62 \\
\hline & & Kimotripsinom katalizirana sinteza peptida & 63 \\
\hline & & Stereoselektivne reakcije & 64 \\
\hline & & Lipazom katalizirana esterifikacija & 34 \\
\hline & $\mathrm{ChCl}: \mathrm{EG}$ i $\mathrm{ChCl}: \mathrm{U}$ & Reakcije peroksidacije & 65 \\
\hline & \multirow{3}{*}{$\mathrm{ChCl}$ : Gly } & Izomerizacija alil alkohola u karbonile & 66 \\
\hline & & Enantioselektivne aldolne reakcije & 67 \\
\hline & & Cikloizomerizacija terminalnih alkina & 68 \\
\hline \multirow{4}{*}{ 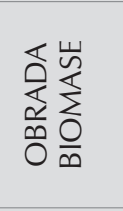 } & $\mathrm{ChCl}: \mathrm{AA}, \mathrm{ChCl}: \mathrm{LA}$ i $\mathrm{ChCl}: \mathrm{FA}$ & Bubrenje celuloza & 69 \\
\hline & $\mathrm{ChCl}: \mathrm{AA}, \mathrm{ChCl}: \mathrm{LA}$ i $\mathrm{ChCl}: \mathrm{FA}$ & Otapanje celuloze & 69 \\
\hline & $\mathrm{ChCl}$ : Glc i $\mathrm{ChCl}$ : LA & Otapanje škroba iz biomase & 19 \\
\hline & $\mathrm{ChCl}: \mathrm{OxA}, \mathrm{ChCl}$ : Gly i $\mathrm{ChCl}: \mathrm{U}$ & Otapanje lignina & 70 \\
\hline \multirow{4}{*}{ 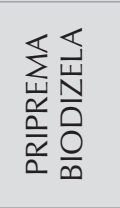 } & $\mathrm{ChCl}: \mathrm{U}$ & Lipazom katalizirana transesterifikacija ulja & 71 \\
\hline & $\mathrm{ChCl}$ : EG i ChCl : Gly & Uklanjanje glicerola & 72 \\
\hline & $\mathrm{ChCl}$ : Gly & Kataliza s $\mathrm{NaOH}$ & 73 \\
\hline & $\mathrm{ChCl}: \mathrm{ZnCl}$ & Kataliza Lewisovim kiselinama & 74 \\
\hline
\end{tabular}




\begin{tabular}{|c|c|c|c|}
\hline & Niskotemperaturno eutektičko otapalo & Proces/reakcija/produkt & Ref. \\
\hline \multirow{7}{*}{ 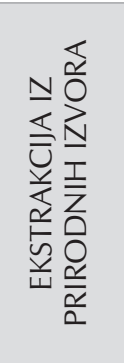 } & $\mathrm{ChCl}$ : Gly & Proteini (BSA) & 75 \\
\hline & $\mathrm{ChCl}: \mathrm{OxA}$ & Peptidi kolagena & 76 \\
\hline & $\mathrm{ChCl}: \mathrm{U}$ & Keratin & 77 \\
\hline & $\mathrm{ChCl}: \mathrm{Mal}$ & Polifenoli & 78 \\
\hline & $\mathrm{ChCl}: \mathrm{OxA}$ & Flavonoidi & 28 \\
\hline & $\mathrm{ChCl}: \mathrm{CA}$ & Antocijani & 30 \\
\hline & $\mathrm{ChCl}$ : LA, ChCl: LeA, ChCl: Gly i Ch: AA & Hemiceluloza, celuloza i lignin & 79 \\
\hline \multirow{6}{*}{ 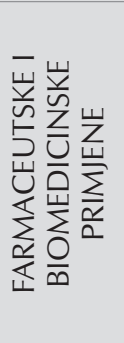 } & $\mathrm{ChCl}: \mathrm{U}$ i $\mathrm{ChCl}: \mathrm{MA}$ & Poboljšana topljivost lijekova (u usporedbi s vodom) & 80 \\
\hline & $\begin{array}{l}\text { Lidokain hidroklorid : ArA i } \\
\text { Lidokain hidroklorid : mArA }\end{array}$ & Kontrolirano otpuštanje zarobljenih aktivnih djelatnih tvari & 81 \\
\hline & Ibuprofen : C16:0 & Terapeutsko niskotemperaturno eutektičko otapalo & 82 \\
\hline & $\mathrm{ChCl}$ : $\mathrm{EG} \mathrm{i} \mathrm{ChCl:} \mathrm{Gly}$ & Pohrana DNK & 83 \\
\hline & $\mathrm{ChCl}: \mathrm{U}$ & Zlatne nanočestice & 84 \\
\hline & Oktan-1,8-diol : halid:CA & Biorazgradljivi poliesteri s antibakterijskom aktivnošću & 85 \\
\hline
\end{tabular}

otapala za industrijsku primjenu je izniman. No, s obzirom na njihova fizikalno-kemijska svojstva, nameće se nekoliko izazova primjene tih otapala u industrijskom mjerilu. Primjerice, činjenica da ta otapala imaju izrazito nizak tlak pare, što pogoduje ekološkom aspektu primjene tih otapala, može otežavati izolaciju i pročišćavanje završnog proizvoda (organska otapala koja zamjenjuju relativno se jednostavno mogu ukloniti uparavanjem). Nadalje, viskoznost niskotemperaturnih eutektičkih otapala može predstavljati izazov tijekom pumpanja, miješanja i održavanja željenog protoka tijekom određenog procesa u kojem se ona primjenjuju, ali također dovesti i do nekih praktičnih problema, poput prijenosa tvari. ${ }^{23}$ Također, važno je istaknuti da je dosadašnja potraga odnosno probir za "idealnim" niskotemperaturnim eutektičkim otapalom za određenu primjenu (među iznimno velikim brojem strukturno različitih otapala), uz neke smjernice dostupne u znanstvenoj literaturi, vođena empirijskim pristupom pokušaja i pogreške, dok je sistematsko istraživanje struktura - svojstva, kao okosnice racionalnog dizajna tih otapala za specifične namjene, još uvijek u povojima. To je izravna posljedica nedostatka temeljnih znanja o tim otpalima, što onemogućava potpuno razumijevanje njihove mehanističke uloge u različitim procesima. Također, primjenom matematičkih modela u dizajniranju niskotemperaturnih eutektičkih otapala ubrzao bi se postupak provjere mogućih kombinacija donora i akceptora vodikove veze te smanjile potrebne količine kemikalija i energije rabljenih u procesu odabira optimalnog sustava, što bi u konačnici bilo od iznimnog ekonomskog i ekološkog značaja. Trenutačno se Conductor-like Screening Model for Real Solvents (COSMO-RS) smatra jednom od najtočnijih ab initio računskih metoda dostupnih za gore navedeno. ${ }^{87}$ Stoga, prikupljanje podataka o osnovnim svojstvima tih otapala te razvoj matematičkih metoda kao alata za njihovo dizajniranje s optimalnim svojstvima za specifičnu namjenu predstavlja glavni izazov koji prethodi industrijskoj primjeni tih otapala.

\section{Zaključak}

Niskotemperaturna eutektička otapala, zbog jedinstvenih fizikalno-kemijskih svojstava, zelenog karaktera, povoljne cijene te mogućnosti dizajniranja za specifične namjene predstavljaju jedinstvena otapala s vrlo izglednom primjenom u kemijskoj i procesnoj tehnologiji, biotehnologiji, prehrambenoj tehnologiji, farmaceutskoj industriji i biomedicini. Sa stanovišta ekonomske učinkovitosti, ta otapala omogućavaju unaprjeđenje postojećih i uspostavljanje novih procesa, ali i osiguravaju vođenje procesa sigurnih za ljude i okoliš. Međutim, proširenje temeljnih istraživanja o svojstvima tih otapala, kao i razvoj matematičkih modela kao alata za njihovo dizajniranje, predstavlja nužan korak prije njihove primjene $u$ industriji.

\section{ZAHVALA}

Hvala prof. dr. sc. Jasni Vorkapić-Furač, koja nas je uvela u svijet zelene kemije, istraživanja i razvoja novih, zelenih otapala, te time prenijela na nas interes i ljubav prema njoj najdražoj organskoj kemiji. Rad je napisan u sklopu projekta Hrvatske zaklade za znanost "Racionalan dizajn prirodnih eutektičkih otapala za pripravi u formulaciju kiralnih lijekova" (br. 7712).

\section{Popis kratica i simbola List of abbreviations and symbols}

$$
\begin{array}{ll}
\rho & - \text { gustoća, } \mathrm{g} \mathrm{cm}^{-3} \\
& - \text { density, } \mathrm{g} \mathrm{cm}^{-3} \\
\eta & - \text { viskoznost } \\
& - \text { viscosity, Pa s } \\
\text { AA } & \text { - octena kiselina } \\
& \text { - acetic acid } \\
\text { ArA } & \text { - akrilna kiselina } \\
& - \text { acrylic acid }
\end{array}
$$




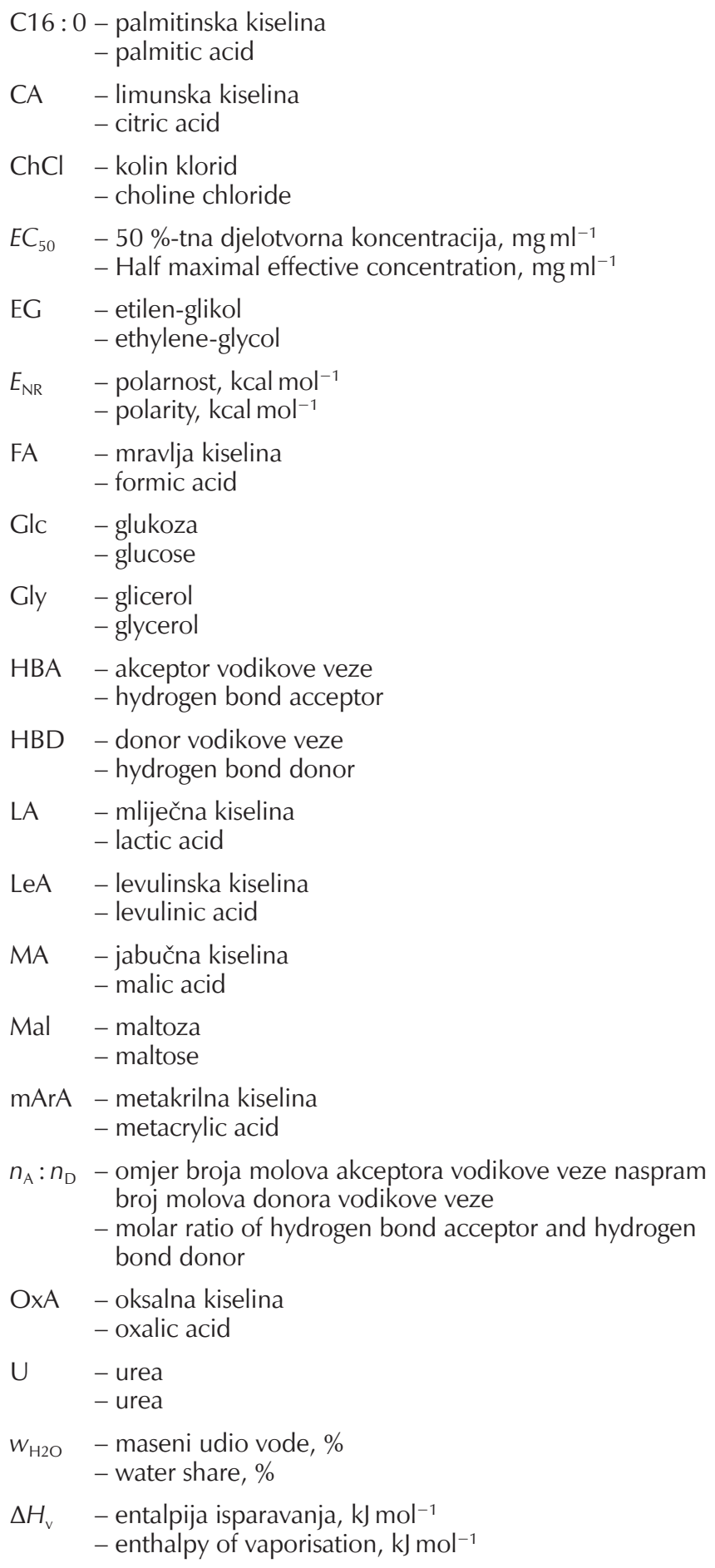

\section{Literatura \\ References}

1. M. Cvjetko Bubalo, K. Radošević, I. Radojčić Redovniković, J. Halambek, I. Vorkapić-Furač, V. Gaurina, J. Srček, lonske kapljevine - Razvoj i izazovi industrijske primjene, Kem. Ind. 63 (2014) 163-171, doi: https://doi.org/10.15255/ KUI.2013.003.

2. European Council, Directive 2010/75/EU Industrial Emissions, Official Journal of the European Union. L334 (2010) 17-119, doi:

3. https://doi.org/10.3000/17252555.L_2010.334.eng.
4. D. Prat, O. Pardigon, H. W. Flemming, S. Letestu, V. Ducandas, P. Isnard, E. Guntrum, T. Senac, S. Ruisseau, P. Cruciani, P. Hosek, Sanofi's Solvent Selection Guide: A Step Toward More Sustainable Processes, Org. Process. Res. Dev. 17 (2013) 1517-1525, doi: https://doi.org/10.1021/ op4002565.

5. M. Cvjetko Bubalo, S. Vidović, I. Radojčić Redovniković, S. Jokić, Green solvents for green technologies, J. Chem. Technol. Biot. 90 (2015) 1631-1639, doi: https://doi. org/10.1002/jctb.4668.

6. A. P. Abbott, G. Capper, D. L. Davies, R. K. Rasheed, V. Tambyrajah, Novel solvent properties of choline chloride/ urea mixtures, Chem. Commun. (2003) 70-71, doi: https:// doi.org/10.1039/b210714g.

7. M. A. R. Martins, S. P. Pinho, J. A. P. Coutinho, Insights into the Nature of Eutectic and Deep Eutectic Mixtures, J. Solution Chem. 48 (2019) 962-982, doi: https://doi.org/10.1007/ s10953-018-0793-1.

8. A. Paiva, R. Craveiro, I. Aroso, M. Martins, R. L. Reis, A. R. C. Duarte, Natural deep eutectic solvents - Solvents for the 21st century, ACS Sustain. Chem. Eng. 2 (2014) 1063-1071, doi: https://doi.org/10.1021/sc500096j.

9. Q. Zhang, K. De Oliveira Vigier, S. Royer, F. Jérôme, Deep eutectic solvents: Syntheses, properties and applications, Chem. Soc. Rev. 41 (2012) 7108-7146, doi: https://doi. org/10.1039/c2cs35178a.

10. R. A. Sheldon, The $E$ factor 25 years on: The rise of green chemistry and sustainability, Green Chem. 19 (2017) 18-43, doi: https://doi.org/10.1039/c6gc02157c.

11. E. L. Smith, A. P. Abbott, K. S. Ryder, Deep Eutectic Solvents (DESs) and Their Applications, Chem. Rev. 114 (2014) 11060-11082, doi: https://doi.org/10.1021/cr300162p.

12. N. Guajardo, H. P. Domínguez de María, K. Ahumada, R. A. Schrebler, R. Ramírez-Tagle, F. A. Crespo, C. Carlesi, Water as Cosolvent: Nonviscous Deep Eutectic Solvents for Efficient Lipase-Catalyzed Esterifications, Chem. Cat. Chem. 9 (2017) 1393-1396, doi: https://doi.org/10.1002/cctc.201601575.

13. E. Durand, J. Lecomte, B. Baréa, G. Piombo, E. Dubreucq, $P$. Villeneuve, Evaluation of deep eutectic solvents as new media for Candida antarctica B lipase catalyzed reactions, Process. Biochem. 47 (2012) 2081-2089, doi: https://doi. org/10.1016/j.procbio.2012.07.027.

14. Scientific Opinion on safety and efficacy of choline chloride as a feed additive for all animal species, EFSA Journal. 9 (2011). https://doi.org/10.2903/j.efsa.2011.2353.

15. Y. Liu, J. B. Friesen, J. B. McAlpine, D. C. Lankin, S. N. Chen, G. F. Pauli, Natural Deep Eutectic Solvents: Properties, Applications, and Perspectives, J. Nat. Prod. 81 (2018) 679-690, doi: https://doi.org/10.1021/acs.jnatprod.7b00945.

16. A. Wang, L. Chen, D. Jiang, H. Zeng, Z. Yan, Vegetable oilbased ionic liquid microemulsion biolubricants: Effect of integrated surfactants, Ind. Crop. Prod. 62 (2014) 515-521, doi: https://doi.org/10.1016/j.indcrop.2014.09.031.

17. I. M. Aroso, R. Craveiro, Â. Rocha, M. Dionísio, S. Barreiros, R. L. Reis, A. Paiva, A. R. C. Duarte, Design of controlled release systems for THEDES - Therapeutic deep eutectic solvents, using supercritical fluid technology, Int. J. Pharm. 492 (2015) 73-79, doi: https://doi.org/10.1016/j.ijpharm.2015.06.038.

18. P. Xu, G. W. Zheng, M. H. Zong, N. Li, W. Y. Lou, Recent progress on deep eutectic solvents in biocatalysis, Bioresour. Bioprocess. 4 (2017) 34, doi: https://doi.org/10.1186/ s40643-017-0165-5.

19. C. Florindo, F. S. Oliveira, L. P. N. Rebelo, A. M. Fernandes, I. M. Marrucho, Insights into the synthesis and properties of deep eutectic solvents based on cholinium chloride and 
carboxylic acids, ACS Sustain. Chem. Eng. 2 (2014) 24162425, doi: https://doi.org/10.1021/sc500439w.

20. Y. Dai, J. van Spronsen, G. J. Witkamp, R. Verpoorte, Y. H. Choi, Natural deep eutectic solvents as new potential media for green technology, Anal. Chim. Acta. 766 (2013) 61-68, doi: https://doi.org/10.1016/j.aca.2012.12.019.

21. A. P. Abbott, D. Boothby, G. Capper, D. L. Davies, R. K. Rasheed, Deep Eutectic Solvents formed between choline chloride and carboxylic acids: Versatile alternatives to ionic liquids, J. Am. Chem. Soc. 126 (2004) 9142-9147, doi: https:// doi.org/10.1021/ja048266j.

22. M. C. Gutiérrez, M. L. Ferrer, C. R. Mateo, F. Del Monte, Freeze-drying of aqueous solutions of deep eutectic solvents: A suitable approach to deep eutectic suspensions of self-assembled structures, Langmuir. 25 (2009) 5509-5515, doi: https://doi.org/10.1021/la900552b.

23. M. Cvjetko Bubalo, M. Panić, K. Radošević, I. Radojčić Redovniković, Metode priprave eutektičkih otapala, Croatian Journal of Food Technology, Biotechnology and Nutrition. 11 (2016) 164-168, doi: https://www.bib.irb.hr/855151.

24. M. L. Toledo, M. M. Pereira, M. G. Freire, J. P. A. Silva, J. A. P. Coutinho, A. P. M. Tavares, Laccase Activation in Deep Eutectic Solvents, ACS Sustain. Chem. Eng. 7 (2019) 11806-11814, doi: https://doi.org/10.1021/acssuschemeng.9b02179.

25. S. L. Cao, X. Deng, P. Xu, Z. X. Huang, J. Zhou, X. H. Li, M. H. Zong, W. Y. Lou, Highly Efficient Enzymatic Acylation of Dihydromyricetin by the Immobilized Lipase with Deep Eutectic Solvents as Cosolvent, J. Agr. Food Chem. 65 (2017) 2084-2088, doi: https://doi.org/10.1021/acs.jafc.7b00011.

26. P. Zhou, X. Wang, C. Zeng, W. Wang, B. Yang, F. Hollmann, Y. Wang, Deep Eutectic Solvents Enable More Robust Chemoenzymatic Epoxidation Reactions, ChemCatChem 9 (2017) 934-936, doi: https://doi.org/10.1002/cctc.201601483.

27. A. Mitar, M. Panić, J. Prlić Kardum, J. Halambek, A. Sander, K. Zagajski Kučan, I. Radojčić Redovniković, K. Radošević, Physicochemical properties, cytotoxicity, and antioxidative activity of natural deep eutectic solvents containing organic acid, Chem. Biochem. Eng. Q 33 (2019) 1-18, doi: https:// doi.org/10.15255/CABEQ.2018.1454.

28. O. S. Hammond, D. T. Bowron, K. J. Edler, The Effect of Water upon Deep Eutectic Solvent Nanostructure: An Unusual Transition from Ionic Mixture to Aqueous Solution, Angew. Chemie Int. Ed. 56 (2017) 9782-9785, doi: https://doi. org/10.1002/anie.201702486.

29. M. Cvjetko Bubalo, N. Ćurko, M. Tomašević, K. Kovačević Ganić, I. Radojčić Redovniković, Green extraction of grape skin phenolics by using deep eutectic solvents, Food Chem. 200 (2016) 159-166, doi: https://doi.org/10.1016/j.foodchem.2016.01.040

30. M. Cvjetko Bubalo, M. Mazur, K. Radošević, I. Radojčić Redovniković, Baker's yeast-mediated asymmetric reduction of ethyl 3-oxobutanoate in deep eutectic solvents, Process Biochem. 50 (2015) 1788-1792, doi: https://doi.org/10.1016/j. procbio.2015.07.015

31. M. Panić, V. Gunjević, G. Cravotto, I. Radojčić Redovniković, Enabling technologies for the extraction of grape-pomace anthocyanins using natural deep eutectic solvents in up-tohalf-litre batches extraction of grape-pomace anthocyanins using NADES, Food Chem. 300 (2019), doi: https://doi. org/10.1016/j.foodchem.2019.125185.

32. B. D. Ribeiro, C. Florindo, L. C. Iff, M. A. Z. Coelho, I. M. Marrucho, Menthol-based eutectic mixtures: Hydrophobic low viscosity solvents, ACS Sustain. Chem. Eng. 3 (2015) 2469-2477, doi: https://doi.org/10.1021/acssuschemeng.5b00532.
33. M. Panić, M. Cvjetko Bubalo, I. Radojčić Redovniković, Designing a biocatalytic process involving deep eutectic solvents, J. Chem. Technol. Biot. (2020), doi: https://doi. org/10.1002/jctb.6545.

34. A. Satlewal, R. Agrawal, S. Bhagia, J. Sangoro, A. J. Ragauskas, Natural deep eutectic solvents for lignocellulosic biomass pretreatment: Recent developments, challenges and novel opportunities, Biotechnol. Adv. 36 (2018) 2032-2050, doi: https://doi.org/10.1016/j.biotechadv.2018.08.009.

35. M. Cvjetko Bubalo, A. Jurinjak Tušek, M. Vinković, K. Radošević, V. Gaurina Srček, I. Radojčić Redovniković, Cholinium-based deep eutectic solvents and ionic liquids for lipase-catalyzed synthesis of butyl acetate, J. Mol. Catal. B-Enzym. 122 (2015) 188-198, doi: https://doi.org/10.1016/j. molcatb.2015.09.005.

36. K. Radošević, I. Čanak, M. Panić, K. Markov, M. Cvjetko Bubalo, J. Frece, V. Gaurina Srček, I. Radojčić Redovniković, Antimicrobial, cytotoxic and antioxidative evaluation of natural deep eutectic solvents, Environ. Sci. Pollut. Res. Int. 25 (2018) 14188-14196, doi: https://doi.org/10.1007/s11356018-1669-z.

37. K. Radošević, N. Ćurko, V. Gaurina Srček, M. Cvjetko Bubalo, M. Tomašević, K. Kovačević Ganić, I. Radojčić Redovniković, Natural deep eutectic solvents as beneficial extractants for enhancement of plant extracts bioactivity, LWT - Food Sci. Technol. 73 (2016) 45-51, doi: https://doi.org/10.1016/j. Iwt.2016.05.037.

38. K. Alfonsi, J. Colberg, P. J. Dunn, T. Fevig, S. Jennings, T. A. Johnson, H. P. Kleine, C. Knight, M. A. Nagy, D. A. Perry, M. Stefaniak, Green chemistry tools to influence a medicinal chemistry and research chemistry based organisation, Green Chem. 10 (2008) 31-36, doi: https://doi.org/10.1039/ b711717e.

39. M. Hayyan, M. A. Hashim, A. Hayyan, M. A. Al-Saadi, I. M. AlNashef, M. E. S. Mirghani, O. K. Saheed, Are deep eutectic solvents benign or toxic?, Chemosphere 90 (2013) 2193-2195, doi: https://doi.org/10.1016/j.chemosphere.2012.11.004

40. M. Hayyan, Y. P. Mbous, C. Y. Looi, W. F. Wong, A. Hayyan, Z. Salleh, O. Mohd-Ali, Natural deep eutectic solvents: cytotoxic profile, SpringerPlus 5 (2016) 913, doi: https://doi. org/10.1186/s40064-016-2575-9.

41. Q. Wen, J. X. Chen, Y. L. Tang, J. Wang, Z. Yang, Assessing the toxicity and biodegradability of deep eutectic solvents, Chemosphere 132 (2015) 63-69, doi: https://doi. org/10.1016/j.chemosphere.2015.02.061.

42. K. Radošević, M. Cvjetko Bubalo, V. Gaurina Srček, D. Grgas, T. Landeka Dragičević, I. Radojčić Redovniković, Evaluation of toxicity and biodegradability of choline chloride based deep eutectic solvents, Ecotox. Environ. Safe. 112 (2015) 46-53, doi: https://doi.org/10.1016/j.ecoenv.2014.09.034.

43. B. Y. Zhao, P. Xu, F. X. Yang, H. Wu, M. H. Zong, W. Y. Lou, Biocompatible Deep Eutectic Solvents Based on Choline Chloride: Characterization and Application to the Extraction of Rutin from Sophora japonica, ACS Sustain. Chem. Eng. 3 (2015) 2746-2755, doi: https://doi.org/10.1021/acssuschemeng. 5 b00619.

44. B. M. Trost, Atom Economy - A Challenge for Organic Synthesis: Homogeneous Catalysis Leads the Way, Angew. Chem. Int. Edit. 34 (1995) 259-281, doi: https://doi. org/10.1002/anie.199502591.

45. R. A. Sheldon, E factors, green chemistry and catalysis: An odyssey, Chem. Commun. 39 (2008) 3352-3365, doi: https://doi.org/10.1039/b803584a.

46. URL: https://www.sigmaaldrich.com/austria.html (15.10.2020.)

47. Y. C. Hou, C. F. Yao, W. Z. Wu, Deep eutectic solvents: Green 
solvents for separation applications, Acta Phys. - Chim. Sin. 34 (2018) 873-885, doi: https://doi.org/10.3866/PKU. WHXB201802062.

48. A. Renjith, A. Roy, V. Lakshminarayanan, In situ fabrication of electrochemically grown mesoporous metallic thin films by anodic dissolution in deep eutectic solvents, J. Colloid. Interf. Sci. 426 (2014) 270-279., doi: https://doi.org/10.1016/j. jcis.2014.04.015.

49. A. Li, Y. Chen, W. Duan, C. Wang, K. Zhuo, Shape-controlled electrochemical synthesis of Au nanocrystals in reline: control conditions and electrocatalytic oxidation of ethylene glycol, RSC Adv. 7 (2017) 19694-19700, doi: https://doi. org/10.1039/C7RA01639E.

50. P. Guillamat, M. Cortés, E. Vallés, E. Gómez, Electrodeposited CoPt films from a deep eutectic solvent, Surf. Coat. Tech. 206 (2012) 4439-4448, doi: https://doi.org/10.1016/j.surfcoat.2012.04.093.

51. X. Xie, X. Zou, X. Lu, K. Zheng, H. Cheng, Q. Xu, Z. Zhou, Voltammetric Study and Electrodeposition of $\mathrm{Cu}$ from $\mathrm{CuO}$ in Deep Eutectic Solvents, J. Electrochem. Soc. 163 (2016) D537-D543, doi: https://doi.org/10.1149/2.1241609jes.

52. A. P. Abbott, K. El Ttaib, K. S. Ryder, E. L. Smith, Electrodeposition of nickel using eutectic based ionic liquids, T. I. Met. Finish. 86 (2008) 234-240, doi: https://doi. org/10.1179/174591908X327581.

53. J. Ru, Y. Hua, C. Xu, J. Li, Y. Li, D. Wang, K. Gong, Z. Zhou, Preparation of sub-micrometer lead wires from $\mathrm{PbO}$ by electrodeposition in choline chloride-urea deep eutectic solvent, Adv. Powder Technol. 26 (2015) 91-97, doi: https://doi. org/10.1016/j.apt.2014.08.008.

54. L. Wei, Z. Y. Zhou, S. P. Chen, C. D. Xu, D. Su, M. E. Schuster, S. G. Sun, Electrochemically shape-controlled synthesis in deep eutectic solvents: Triambic icosahedral platinum nanocrystals with high-index facets and their enhanced catalytic activity, Chem. Commun. 49 (2013) 11152-11154, doi: https://doi.org/10.1039/c3cc46473c.

55. J. A. Hammons, J. Ustarroz, T. Muselle, A. A. J. Torriero, H. Terryn, K. Suthar, J. Ilavsky, Supported silver nanoparticle and near-interface solution dynamics in a deep eutectic solvent, J. Phys. Chem. C 120 (2016) 1534-1545, doi: https://doi. org/10.1021/acs.jpcc.5b09836.

56. P. K. Wang, Y. T. Hsieh, I. W. Sun, On the Electrodeposition of Arsenic in a Choline Chloride/Ethylene Glycol Deep Eutectic Solvent, J. Electrochem. Soc. 164 (2017) D204-D209, doi: https://doi.org/10.1149/2.1061704jes.

57. P. Sebastián, E. Vallés, E. Gómez, Copper electrodeposition in a deep eutectic solvent. First stages analysis considering $\mathrm{Cu}(\mathrm{I})$ stabilization in chloride media, Electrochim. Acta 123 (2014) 285-295, doi: https://doi.org/10.1016/j.electacta.2014.01.062.

58. B. T. Yonemoto, Z. Lin, F. Jiao, A general synthetic method for MPO4 (M = Co, Fe, Mn) frameworks using deep-eutectic solvents, Chem. Commun. 48 (2012) 9132-9134, doi: https://doi.org/10.1039/c2cc34020h.

59. T. Gu, M. Zhang, J. Chen, H. Qiu, A novel green approach for the chemical modification of silica particles based on deep eutectic solvents, Chem. Commun. 51 (2015) 9825-9828, doi: https://doi.org/10.1039/c5cc02553b.

60. F. Chen, S. Xie, X. Huang, X. Qiu, lonothermal synthesis of Fe 3 O 4 magnetic nanoparticles as efficient heterogeneous Fenton-like catalysts for degradation of organic pollutants with $\mathrm{H}_{2} \mathrm{O}_{2}$, J. Hazard Mater. 322 (2017) 152-162, doi: https://doi.org/10.1016/j.jhazmat.2016.02.073.

61. H. Zhang, Y. Lu, C. D. Gu, X. L. Wang, J. P. Tu, Ionothermal synthesis and lithium storage performance of core/ shell structured amorphous@crystalline Ni-P nanoparticles,
Cryst. Eng. Comm. 14 (2012) 7942-7950, doi: https://doi. org/10.1039/c2ce25939g.

62. G. F. Cai, J. P. Tu, C. D. Gu, J. H. Zhang, J. Chen, D. Zhou, S. J. Shi, X. L. Wang, One-step fabrication of nanostructured $\mathrm{NiO}$ films from deep eutectic solvent with enhanced electrochromic performance, J. Mater. Chem. A 1 (2013) 4286-4292, doi: https://doi.org/10.1039/c3ta01055d.

63. S. B. Phadtare, G. S. Shankarling, Halogenation reactions in biodegradable solvent: Efficient bromination of substituted 1-aminoanthra-9,10-quinone in deep eutectic solvent (choline chloride: Urea), Green Chem. 12 (2010) 458-46, doi: https://doi.org/10.1039/b923589b.

64. Z. Maugeri, W. Leitner, P. Domínguez De María, Chymotrypsin-catalyzed peptide synthesis in deep eutectic solvents, Eur. J. Org. Chem. 2013 (2013) 4223-4228, doi: https://doi. org/10.1002/ejoc.201300448.

65. E. Massolo, S. Palmieri, M. Benaglia, V. Capriati, F. M. Perna, Stereoselective organocatalysed reactions in deep eutectic solvents: Highly tunable and biorenewable reaction media for sustainable organic synthesis, Green Chem. 18 (2016) 792-797, doi: https://doi.org/10.1039/c5gc01855b.

66. A. A. Papadopoulou, E. Efstathiadou, M. Patila, A. C. Polydera, H. Stamatis, Deep Eutectic Solvents as Media for Peroxidation Reactions Catalyzed by Heme-Dependent Biocatalysts, Ind. Eng. Chem. Res. 55 (2016) 5145-5151, doi: https://doi. org/10.1021/acs.iecr.5b04867.

67. A. K. Sanap, G. S. Shankarling, Eco-friendly and recyclable media for rapid synthesis of tricyanovinylated aromatics using biocatalyst and deep eutectic solvent, Catal. Commun. 49 (2014) 58-62, doi: https://doi.org/10.1016/j.catcom.2014.01.031.

68. R. Martínez, L. Berbegal, G. Guillena, D. J. Ramón, Bio-renewable enantioselective aldol reaction in natural deep eutectic solvents, Green Chem. 18 (2016) 1724-1730, doi: https://doi.org/10.1039/c5gc02526e.

69. C. Vidal, F. J. Suárez, J. García-Álvarez, Deep eutectic solvents (DES) as green reaction media for the redox isomerization of allylic alcohols into carbonyl compounds catalyzed by the ruthenium complex $\left[\mathrm{Ru}\left(\eta 3: \eta 3-\mathrm{C}_{10} \mathrm{H}_{16}\right) \mathrm{Cl}_{2}\right.$ (benzimidazole)], Catal. Commun. 44 (2014) 76-79, doi: https://doi. org/10.1016/j.catcom.2013.04.002.

70. D. Tian, Y. Guo, J. Hu, G. Yang, J. Zhang, L. Luo, Y. Xiao, S. Deng, O. Deng, W. Zhou, F. Shen, Acidic deep eutectic solvents pretreatment for selective lignocellulosic biomass fractionation with enhanced cellulose reactivity, Int. J. Biol. Macromol. 142 (2020) 288-297, doi: https://doi.org/10.1016/j. ijbiomac.2019.09.100.

71. Y. Liu, W. Chen, Q. Xia, B. Guo, Q. Wang, S. Liu, Y. Liu, J. Li, H. Yu, Efficient Cleavage of Lignin-Carbohydrate Complexes and Ultrafast Extraction of Lignin Oligomers from Wood Biomass by Microwave-Assisted Treatment with Deep Eutectic Solvent, Chem. Sus. Chem. 10 (2017) 1692-1700, doi: https://doi.org/10.1002/cssc.201601795.

72. B. Kleiner, P. Fleischer, U. Schörken, Biocatalytic synthesis of biodiesel utilizing deep eutectic solvents: A two-step-onepot approach with free lipases suitable for acidic and used oil processing, Process Biochem. 51 (2016) 1808-1816, doi: https://doi.org/10.1016/j.procbio.2015.10.016.

73. X. D. Hou, G. J. Feng, M. Ye, C. M. Huang, Y. Zhang, Significantly enhanced enzymatic hydrolysis of rice straw via a high-performance two-stage deep eutectic solvents synergistic pretreatment, Bioresource Technol. 238 (2017) 139-146, doi: https://doi.org/10.1016/j.biortech.2017.04.027.

74. T. Homan, K. Shahbaz, M. M. Farid, Improving the production of propyl and butyl ester-based biodiesel by purification using deep eutectic solvents, Sep. Purif. Technol. 
174 (2017) 570-576, doi: https://doi.org/10.1016/j.seppur.2016.10.036.

75. T. Long, Y. Deng, S. Gan, J. Chen, Application of choline chloride $\times \mathrm{ZnCl}_{2}$ ionic liquids for preparation of biodiesel, Chinese J. Chem. Eng. 18 (2010) 322-327, doi: https://doi. org/10.1016/S1004-9541(08)60359-6.

76. K. Xu, Y. Wang, Y. Huang, N. Li, Q. Wen, A green deep eutectic solvent-based aqueous two-phase system for protein extracting, Anal. Chim. Acta 864 (2014) 9-20, doi: https:// doi.org/10.1016/j.aca.2015.01.026.

77. C. Bai, Q. Wei, X. Ren, Selective Extraction of Collagen Peptides with High Purity from Cod Skins by Deep Eutectic Solvents, ACS Sustain. Chem. Eng. 5 (2017) 7220-7227, doi: https://doi.org/10.1021/acssuschemeng.7b01439.

78. K. E. Moore, D. N. Mangos, A. D. Slattery, C. L. Raston, R. A. Boulos, Wool deconstruction using a benign eutectic melt, RSC Adv. 6 (2016) 20095-20101, doi: https://doi. org/10.1039/c5ra26516a

79. Z. Wei, X. Qi, T. Li, M. Luo, W. Wang, Y. Zu, Y. Fu, Application of natural deep eutectic solvents for extraction and determination of phenolics in Cajanus cajan leaves by ultra performance liquid chromatography, Sep. Purif. Technol. 149 (2015) 237-244, doi: https://doi.org/10.1016/j.seppur.2015.05.015.

80. C. Alvarez-Vasco, R. Ma, M. Quintero, M. Guo, S. Geleynse, K. K. Ramasamy, M. Wolcott, X. Zhang, Unique low-molecular-weight lignin with high purity extracted from wood by deep eutectic solvents (DES): A source of lignin for valorization, Green Chem. 18 (2016) 5133-5141, doi: https://doi. org/10.1039/c6gc01007e.

81. H. G. Morrison, C. C. Sun, S. Neervannan, Characterization of thermal behavior of deep eutectic solvents and their potential as drug solubilization vehicles, Int. J. Pharm. 378 (2009) 136-139, doi: https://doi.org/10.1016/j. ijpharm.2009.05.039.

82. R. J. Sánchez-Leija, J. A. Pojman, G. Luna-Bárcenas, J. D. Mota-Morales, Controlled release of lidocaine hydrochloride from polymerized drug-based deep-eutectic solvents, J. Mater. Chem. B 2 (2014) 7495-7501, doi: https://doi. org/10.1039/c4tb01407c

83. S. Benessam, K. Khimeche, F. Djellouli, M. Benziane, A. Dahmani, Phase diagram of ibuprofen with fatty acids, J. Therm. Anal. Calorim. 112 (2013) 317-320, doi: https://doi. org/10.1007/s10973-012-2831-3.

84. D. Mondal, M. Sharma, C. Mukesh, V. Gupta, K. Prasad, Improved solubility of DNA in recyclable and reusable biobased deep eutectic solvents with long-term structural and chemical stability, Chem. Commun. 49 (2013) 9606-9608, doi: https://doi.org/10.1039/c3cc45849k.

85. V. S. Raghuwanshi, M. Ochmann, A. Hoell, F. Polzer, K. Rademann, Deep eutectic solvents for the self-assembly of gold nanoparticles: A SAXS, UV-Vis, and TEM investigation, Langmuir 30 (2014) 6038-6046, doi: https://doi.org/10.1021/ la500979p.

86. S. García-Argüelles, M. C. Serrano, M. C. Gutiérrez, M. L. Ferrer, L. Yuste, F. Rojo, F. Del Monte, Deep eutectic solvent-assisted synthesis of biodegradable polyesters with antibacterial properties, Langmuir 29 (2013) 9525-9534, doi: https:// doi.org/10.1021/la401353r.

87. R. Craveiro, F. Mano, A. Paiva, A. R. C. Duarte, Deep Eutectic Solvents: Exploring Their Role in Nature, u D. J. Ramon and G. Guillena (ur.), Deep Eutectic solvents: Synthesis, Properties, and Applications, Wiley, Weinheim, 2019, str. 95-110. https://doi.org/10.1002/9783527818488.ch6.

88. A. Klamt, V. Jonas, T. Bürger, J. C. W. Lohrenz, Refinement and parametrization of COSMO-RS, J. Phys. Chem. A 102 (1998) 5074-5085, doi: https://doi.org/10.1021/jp980017s.

\section{SUMMARY \\ Deep Eutectic Solvents - Creating a Green Solvent for the Future through Rational Design \\ Mia Radović, Manuela Panić, Kristina Radošević, Marina Cvjetko Bubalo, and Ivana Radojčić Redovniković}

Deep eutectic solvents arose as substitutes for harmful industrial solvents, as they fully meet the principles of green chemistry. Their structure and physicochemical properties can be designed for specific purposes, so they have proven to be effective in various fields such as electrochemistry, organic synthesis and (bio)catalysis, biotechnology and food technology, pharmaceutical engineering and biomedicine, where they can fulfil the technological and economic demands of the industry. This paper provides a literature overview of the characteristic properties, preparation, and application of deep eutectic solvents, but also the challenges of their application on an industrial scale.

\section{Keywords}

Green chemistry, green solvents, deep eutectic solvents, rational design, designed solvents

Faculty of Food Technology

and Biotechnology,

University of Zagreb,

Pierrotijeva 6

10000 Zagreb, Croatia
Review

Received November 16, 2020 Accepted February 7, 2021 